\title{
Struktur dan Sistem Sosial pada Aras Wacana dan Praksis
}

\author{
Thohir Yuli Kusmanto, ${ }^{1}$ Misbah Zulfa Elizabeth ${ }^{2}$ \\ Fakultas Ilmu Sosial dan Ilmu Politik Universitas Islam Negeri Walisongo, Semarang \\ (e-mail: ${ }^{1}$ thohiryuli@walisongo.ac.id; ${ }^{2}$ zulfa_elizabeth@walisongo.ac.id)
}

\begin{abstract}
The social phenomenon that became the focus of sociology has diversity in the aspects of social life of society both as a real and practical reality as well as abstract and utopian reality. The reality is static and moves dynamically inherent in social processes in the daily life of social setting. The social process shapes reality as part of the past takes place today and becomes a hope for the future. Among the social phenomena that become part of the fundamental study of sociology are structure and social system. Social structure is a process of social interaction that lasts a long time, regularly and form a pattern. The social system is a functional social interaction of a set of elements in a group or society to defend the boundaries or unity of its parts. Both in this context are interesting to explain the process of its formation, relationships, functions, traits and changes in discourse and praxis. Applying literature study this article will explore the processes of formation, relationships, functions, traits, and changes of social structure and social system in discourse and praxis. The effort is important to strengthen the sociology repertoire on the macro and abstract level.
\end{abstract}

Fenomena sosial yang menjadi fokus kajian sosiologi sangat beragam eksistensinya dalam berbagai aspek kehidupan sosial masyarakat baik sebagai realitas yang nyata dan praktis maupun realitas abstrak dan utopis. Realitas tersebut bersifat statis dan bergerak secara dinamis melekat dalam proses sosial dalam kehidupan sehari-hari masyarakat. Proses sosial membentuk realitas sebagai bagian masa lalu, berlangsung saat ini, dan menjadi harapan bagi masa depan. Diantara fenomena sosial yang menjadi bagian kajian mendasar sosiologi adalah struktur dan sistem sosial. Struktur sosial merupakan proses interaksi sosial yang berlangsung lama, teratur dan membentuk suatu pola. Sistem sosial merupakan interaksi sosial fungsional seperangkat unsur-unsur dalam kelompok atau masyarakat untuk mempertahankan batas-batas atau kesatuan bagian-bagiannya. Keduanya dalam konteks ini menarik untuk dijelaskan proses pembentukannya, relasi, fungsi, sifat dan perubahannya dalam wacana dan praksis. Upaya tersebut penting untuk memperkuat khasanah keilmuan sosiologi pada aras makro dan abstrak. Dengan menggunakan kajian literatur tulisan ini akan mengungkap proses pembentukan struktur dan sistem sosial, relasi, fungsi, sifat, dan perubahannya dalam aras wacana dan praksis.

Keywords: interaksi sosial; fungsi; sosiologi; wacana; praksis 


\section{Pendahuluan}

Struktur sosial merupakan hubunganhubungan yang terus bertahan, teratur dan terpola di antara unsur-unsur dalam masyarakat. Konsep ini mendasari para sosiolog abad 19 membandingkan masyarakat dengan mesin atau organisme (makhluk hidup) (Abercrombie, Hill, dan Turner 2010: 525). Struktur sosial merupakan bagian yang esensial dalam studi sosiologi hingga saat ini, persebarannya sangat dipengaruhi oleh lokus para sosiolognya. Sebagai kajian esensial sosiologi struktur sosial dipahami pada aras teoretik dan praktis. Bagi kelompok teoretik memposisikan struktur sosial merupakan titik lokus dari komitmen teoretik mereka. Sementara itu sebagian praktisi memahami struktur sosial sebagai sebuah asumsi latar belakang yang keberadaannya sebagai akibat dari adanya proses penelitian mendalam secara teoritis dan empiris (Kuper dan Kuper 2000: 1004)..

Struktur sosial dalam makna yang lain adalah setiap pola berulang dari perilaku sosial, baik perilaku-perilaku yang kurang penting dan atau penting. Smelser (1998) menegaskan bahwa hampir semua ahli strukturalisme menyatakan bahwa struktur sosial merupakan motif dan keinginan yang berada di luar individu. Namun demikian, struktur sosial ini sangat kuat karena menentukan pola perilaku individu sehingga dalam kerangka ini penting untuk dikaji karena dapat menjelaskan penyebab pola perilaku tertentu dalam masyarakat. Pola perilaku sosial yang terorganisasi disebut sebagai institusi sosial oleh sebagian sosiolog, terutama aliran fungsionalisme.
Dalam konteks ini, struktur sosial merupakan hubungan fungsional lembaga-lembaga sosial (Abercrombie et al. 2010: 525). Struktur sosial dalam studi sosiologi sebagai sebuah konsep yang sangat sering digunakan atau diperbincangkan. Secara konseptual konsep struktur sosial menggunakan pendekatan sosiologis ada dua (Abercrombie et al. 2010: 525): 1) Pendekatan fungsionalisme; menjelaskan struktur sosial sebagai pola-pola (susunan) yang dapat dilihat dalam kehidupan sehari-hari. 2) Pendekatan realisme; menjelaskan bahwa struktur sosial merupakan prinsip-prinsip yang mendasari susunan sosial, yang mungkin tidak terlihat.

Perbincangan tentang struktur sosial dalam perspektif sosiologis tidak bisa melepaskan dari sistem sosial. Keduanya merupakan konsep dalam sosiologi untuk memahami dan menjelaskan dinamika sosial sebagai pokok kajian dan pendekatan. Namun demikian sistem bukanlah sesuatu yang khas dalam sosiologi, tetapi peranti konseptual yang diterima secara luas dalam ilmu alam dan sosial (Abercrombie et al. 2010: 526). Sistem sosial merupakan interaksi antar dua aktor sosial atau lebih yang bersifat stabil dalam lingkungan terbatas. Fokus perhatian sistem sosial tidak hanya dalam konteks hubungan antar personal, tetapi juga kelompok, lembaga, masyarakat, dan entitas inter-sosial (Abercrombie et al. 2010: 526). Sistem sosial merupakan hubungan sosial, kelompok atau masyarakat sebagai seperangkat unsur yang saling berhubungan yang berfungsi untuk mempertahankan batas-batas atau kesatuan bagianbagiannya. Oleh karenanya sistem sosial 
seiring waktu memiliki kecenderungan untuk menuju suatu keseimbangan atau "homeostasis" (Abercrombie et al. 2010: 526-527; Wenger 2008: 1-10).

Sistem sosial merupakan kesatuan atau keutuhan suatu entitas sosial yang dibangun melalui organisasi relasi dari komponenkomponen. Tidak ada suatu sistem tanpa kesatuan dan setiap kesatuan selalu dapat dilihat sebagai sistem. Lawan dari sistem sosial adalah kumpulan atau kerumunan yang merupakan komponen-komponen yang kebetulan berada pada ruang yang sama atau kebetulan berdekatan (Muadz 2014:1). Etienne Wenger (2008: 1-10) memberikan banyak ilustrasi mengenai contoh-contoh sistem sosial dalam berbagai konteksnya. Konteks yang membentuk sistem sosial bisa jadi merupakan konteks struktural formal yang telah terbentuk, namun bisa jadi merupakan dampak bentukan konteks struktural-formal. Sebagai contoh mengenai sistem sosial misalnya, dalam sebuah organisasi, di dalamnya berkumpul orang-orang dengan tugas dan fungsi tertentu. Mereka mengerjakan tugas dan fungsi itu adalah untuk mencapai tujuan yang ditetapkan bersama. Antar peran dalam organisasi itu saling berkait satu sama lain untuk saling melengkapi dalam rangka untuk mencapai tujuan organisasi. Namun demikian individu-individu dalam organisasi itu juga memiliki ikatan masing-masing yang tidak berkait dengan tujuan organisasi, namun berkait dengan kepentingan-kepentingan lain, misalnya kesamaan asal daerah, hobi, atau afiliasi sosial lain, sehingga membentuk sistem sosial yang lain.
Sistem sosial merupakan interdependensi fungsional unsur-unsur suatu sistem dalam bentuk gejala-gejala sosial. Struktur sosial merupakan aspek statis dari sistem sosial. Aspek dinamisnya adalah proses sosial yang berupa interaksi sosial (Soekanto 1993: 5253). A.L. Kroeber dan Talcott Parsons (1958: 12) menegaskan bahwa sistem social "designate the specifically relational system of interaction among individuals and collectivities" (sistem sosial merupakan sistem interaksi relasional di antara individu-individu dan kolektifitas).

Sistem sosial sebagai organisasi sosial merupakan pola-pola hubungan antar individu dan kelompok-kelompok, yang timbul dalam interaksi sosial (Soekanto 1993: 52). Durkheim merupakan tokoh awal (klasik) yang menekankan studi sistem dalam sosiologi secara eksplisit (nyata), yang meliputi (Turner dan Maryanski 2010: 168): 1) Studi tentang sistem sosial dalam sosiologi harus mampu menyingkap derajat (tingkat) integrasi internal diantara bagian-bagian sistem (konstituen). 2) Secara teoretik studi tentang sistem sosial mampu mengungkap konsekuensi atau fungsi suatu bagian sistem dalam kontribusinya untuk integrasi keseluruhan sistemik. 3) Ada proses pemisahan dalam menjelaskan 'sebabsebab' dengan 'fungsi-fungsi' bagian dari sistem dalam kontribusinya mewujudkan integrasi keseluruhan sistemik. 4) Kebutuhan akan integrasi sosial yang beroperasi sebagai mekanisme selektif bagi keberlangsungan bagianbagian yang mendorong lahirnya integrasi keutuhan sosial.

Studi sosiologi tentang sistem sosial dalam perkembangan teori modern sosiologi, men- 
jelaskannya dalam beberapa aspek. Semua melekat dalam kehidupan masyarakat yang berproses secara sistematis. Dinamikanya mempengaruhi pembentukan masyarakat dalam sosial dan zaman. Kingsley Davis (1959) (dalam Turner dan Maryanski 2010: 167) memberikan pandangan tentang kajian sosiologi atas sistem sosial dalam beberapa realitas sebagai berikut: 1) Penyelidikan sosiologis menelaah manusia dalam suatuk konteks sistemik. 2) Penyelidikan sosiologis mencoba menemukan latar belakang variasi dalam sistem yang bisa dijelaskan oleh variasi dalam bagian-bagian dalam anggotanya (konstituen). 3) Penyelidikan sosiologis berusaha menemukan mengapa pola-pola sosial tertentu bersifat universal.

Beberapa dialog akademik yang dipaparkan di atas menunjukkan arti penting kajian lanjut mengenai struktur sosial dan dan sistem sosial. Tidak semata dalam aras wacana, namun juga dalam aras praksis. Dengan pertimbangan arti penting tersebut maka perlu dilakukan kajian lanjut mengenai struktur dan sistem sosial dengan batasan: pembentukan struktur dan sistem sosial, relasi, fungsi, sifat, dan perubahannya dalam aras wacana dan praksis. Adapun kajian yang dilakukan dalam rangka mendapatkan penjelasan mengenai hal-hal di atas adalah kajian literatur.

\section{Pembentukan Struktur dan Sistem Sosial dalam Masyarakat}

Pembentukan struktur sosial tidak berlangsung secara instan dalam suatu masyarakat. proses evolutif merupakan pembentukan struktur sosial yang bertahap. Ada be- berapa unsur sosial penting yang menentukan pembentukan struktur sosial tersebut. unsurunsur tersebut meliputi (Susilo 2010: 28): 1) Hubungan timbal balik satuan atau suatu kelompok dengan satuan atau kelompok lainnya. 2) Pola-pola yang abadi dari tingkah laku partisipan dalam sebuah sistem sosial dalam kaitannya dengan yang lain. 3) Normanorma yang telah terinstitusionalisasi atau kerangka-kerangka pengetahuan yang terstruktur yang mendasari tindakan-tindakan para pelaku dalam sistem sosial.

Dinamika sistem sosial dalam masyarakat berkembang sesuai dengan aspek-aspek sosial yang membentuknya, sehingga berkembang sistem sosial yang beragam. Aspek mendasar dari sistem sosial yang bisa membedakan antara sistem sosial yang satu dengan lainnya (Muadz 2014: 1): 1) Memiliki ciri atau berkaitan dengan komponen-komponen sosial. 2) Menggambarkan hubungan fungsional antar komponen sosial satu dengan yang lainnya yang berlansung terus menerus (intersubjektivitas). 3) Memiliki identitas tertentu.

Sistem sosial dalam prosesnya merupakan bagian perkembangan institusi sosial dalam masyarakat. Perkembangan institusi sosial menjadi sistem sosial merupakan konsekuensi dari dinamika kelembagaan, dalam memenuhi kebutuhan anggotanya. Institusi sosial menjadi sistem sosial dilihat dengan pendekatan sistem harus memenuhi dua prasyarat sebagai berikut (Muadz 2014: 4): 1) Semua komponen telah memiliki relasi intersubjektivitas dengan sesama yang tidak pernah berhenti. 2) Relasi intersubjektivitas memiliki pola yang invarian 
dengan organisasi tertentu yang terus menerus dikonservasi, dan tidak pernah berubah.

Dalam perspektif sirkularitas, sistem memiliki mekanisme untuk memberikan informasi pada dirinya dalam bentuk feedback loop, negatif maupun positif, sehingga mampu mengoreksi diri agar ia selalu berada dalam keseimbangan (balancing feedback) (Muadz 2014: 73). Sistem memiliki otonomi penuh karena mekanisme kerjanya dalam bentuk interkoneksi komponen yang terus menerus di dalam batasan (boundary) tertentu melahirkan struktur tertentu dan struktur tersebut selanjutnya mempengaruhi dan membatasi perilaku dan pola-pola hubungan antar komponen (Muadz 2014: 74).

Pembentukan sistem sosial akan menciptakan suatu pola yang bersifat sistemik. Prosesnya ditentukan dinamika individu (aktor) dalam kehidupan masyarakat. Pola-pola sistem sosial berkembang secara dinamis ditentukan posisi individu dalam hubungannya sebagai komponen sistem dalam masyarakat. Berdasarkan pola hubungan tersebut terbagi meliputi (Soekanto 1993: 53): 1) Pola hubungan interpersonal; pola interaksi antar individu dan peranannya dalam menciptakan ketertiban sosial mikro. 2) Pola kelompok; hubungan interpersonal dalam suatu kelompok atau organisasi sehingga mampu menciptakan ketertiban sosial mikro dan makro. 3) Pola tertib sosial; interaksi secara komprehensif organisasi sosial, komunitas, dan masyarakat sehingga menciptakan ketertiban sosial makro.

Sistem sosial memiliki kecenderungan menuju keseimbangan atau memiliki sifat "homeostasis" dan bersifat fungsional sehingga hadir dalam rangka memenuhi sejumlah maksud atau tujuan (Abercrombie et al. 2010: 256). Dinamika sistem sosial ditentukan oleh cara-cara yang digunakan dalam mencapai sejumlah tujuannya. Setiap sistem sosial memiliki tujuannya sendiri-sendiri sehingga cara mencapainya pun berkembang sesuai tujuannya tersebut.

Pelestarian batas (boundary maintenance); merupakan konsep dalam fungsionalisme Parsons (Kroeber dan Parsons 1958) yang menjelaskan bahwa suatu sistem sosial bersifat memelihara batas dalam kaitannya dengan lingkungannya untuk melestarikan keteraturan atau pola tertentu. Diantara upaya mewujudkan kondisi tersebut, sistem sosial kadang-kadang melakukan proses pertukaran sumber daya dengan melintasi perbatasan dengan sistem yang lain (Abercrombie et al. 2010: 49). Kondisi tersebut menjadi proses yang tidak bisa dihindari dalam masyarakat yang terbuka. Diantara satu sistem bersinggungan dan berkaitan membentuk sistem yang lebih luas. Kebutuhan melintas batas suatu sistem, diperlukan untuk mempertahankan eksistensi dan kebutuhan elemenelemen sistem yang terus berubah dan bertambah.

Pembentukan sistem sosial sebagai proses standarisasi perilaku dalam ruang dan waktu, yang mencakup rekonstruksi terus menerus dalam konteks potensial aktivitas sosial seharihari (Giddens 2009: 180). Konteks waktu (temporalitas) merekonstruksi sistem sosial melalui tiga cara, yang meliputi (Giddens 2009: 
180-181): 1) Dalam jalinan interaksi langsung, yang secara potensial dicapai atau dihadirkan oleh para pelaku, sebagai reproduksi sosial dalam pengertiannya yang paling mendasar. 2) Dalam reproduksi anggota sistem sosial, sebagai makhluk dengan rentang waktu yang terbatas, yang tentunya ditanamkan ke dalam reproduksi biologis. 3) Dalam reproduksi institusi, yang diendapkan dalam durasi panjang (long duration) waktu historis.

\section{Sifat-sifat Dasar Struktur dan Sistem Sosial}

Pemikiran tentang struktur sosial diantaranya dilihat sebagai sesuatu yang memiliki rumusan abstrak (tidak nampak). Perspektif ini telah mengesampingkan atau menolak eksistensi kebebasan dan kreativitas manusia. Sifat-sifat individual kurang terakomodasi karena segala tindakan manusia (individu) ditentukan oleh struktur sosial tempat mereka berada dan berkembang (Abercrombie et al. 2010: 525). Individu harus beradaptasi agar bisa diterima menjadi bagian dari struktur sosial yang ada. Dalam proses ini maka harus ada upaya menekan kehendak diri untuk suatu kebebasan karena tuntutan dari struktur sosial adalah bahwa individu tunduk terhadap struktur sosial.

Pada sisi yang lain keberadaan struktur sosial berkaitan erat dengan sistem sosial. Sistem sosial dalam perspektif sosiologis memiliki prinsip otonomi. Sistem sosial dalam idealitasnya memiliki mekanisme organisasi tertentu, yang memungkinkannya mampu membangun dan mengkonservasi secara terus menerus ciri keutuhan dirinya sebagai identitas eksistensialnya. Setiap tekanan baik internal dan eksternal bisa dikelola untuk mendukung perbaikan dan penguatan sistem sehingga tidak mengganggu dan atau merusak elemen-elemen sistem sosial itu sebagai satu kesatuan dalam struktur sosial yang ada.

Kesatuan (unity) dalam sistem sosial sangat ditentukan oleh pilihan individual, yang sifatnya bisa berubah-ubah. Sebagai akibatnya unity menjadi suatu identitas yang belum permanen. Kesatuan (unity) akan tercapai apabila individu telah menjadikan sistem sosial tersebut sebagai visi hidup. Untuk mewujudkannya maka masih memerlukan suatu perjuangan tersendiri secara terus menerus. Pilihan individu atas suatu sistem sosial mengandung dua dimensi (Muadz 2014: 5354): 1) Pilihan rasional terkait dengan pilihan atas alat-alat atau instrumen dalam rangka tujuan-tujuan tertentu. Pilihan rasional merefleksikan nilai-nilai instrumental dan ekstrinsik serta menghindari resiko. 2) Pilihan emosional berkaitan dengan ketertarikan, kegembiraan, kegairahan, dan tantangan serta kepuasan. Sifat dari pilihan emosional adalah intrinsik. Dalam praktiknya pilihan emosional menekankan kebijaksanaan (kearifan), atas dasar etika dan cara melihat konsekuensikonsekuensi perbuatan dalam konteks kebersamaan.

Sifat-sifat dasar dalam pembentukan sistem sosial sangat ditentukan oleh perbedaan-perbedaan tujuan masing-masing individu atau elemen dalam proses pembentukan sistem sosial. Sifat dasar dari sistem sosial menurut 
perbedaan tujuannya meliputi (Muadz 2014: 54): 1) Bersifat reaktif; bahwa sistem sosial pembentukannya atau bertindak dalam rangka untuk mempertahankan diri (self maintaning). Dalam kondisi ini sistem memiliki struktur internal yang mampu memberikan reaksi terhadap perubahan-perubahan eksternal untuk menjaga stabilitasnya menghadapi perbedaan atau perubahan di lingkungannya. 2) Bersifat responsif; bahwa sistem sosial pembentukannya atau bertindak dalam rangka mencapai tujuan yang telah ditetapkan (goal seeking). Sifat ini menunjuk pada kapasitas sistem merespons dengan cara yang berbeda perubahanperubahan kondisi yang berlangsung pada lingkungan yang sama atau berbeda, sehingga menghasilkan keadaan-keadaan tertentu. 3) Bersifat generatif; bahwa sistem sosial pembentukannya atau bertindak dalam rangka mencapai tujuan yang bisa berubah sesuai pilihan bebas yang dimiliki (purposeful).

Dalam konteks struktur sosial di dalam masyarakat, dinamika individu (agent) dalam kehidupannya dibatasi oleh struktur sosial yang ada. Perkembangan masyarakat yang semakin kompleks, mengakibatkan individu harus berhadap-hadapan dengan banyaknya struktur sosial. Keragaman atau perbedaan struktur sosial mengakibatkan individu berada dalam situasi tertekan dan tersiksa dalam kehidupan sosialnya. Gejala tersebut sebagai konsekuensi dari adanya kontradiksi tuntutan struktur sosial. Dalam masyarakat industri secara teoretik struktur sosial mengalami fragmentasi dan diferensiasi (Kuper dan Kuper 2000: 1004).
Dalam proses perubahan masyarakat dari masyarakat tradisional hingga masyarakat industri, secara teoretik struktur sosial mengalami proses fragmentasi dan diferensiasi (Kuper dan Kuper 2000: 1004). Dalam masyarakat tradisional diferensiasi dilakukan secara sederhana, in-group dan out-group, namun dalam masyarakat industri differensiasi tidak hanya berbasis asal kelompok, namun kekuatan, kekuasaan, dan kapital, serta jenis kelamin (Rudjansyah 1997: 44-54).

Dinamika sosial sebagai perilaku seringkali memiliki pertentangan dengan intuisi dan daya nalar biasa. Akibatnya gejala sosial dalam kompleksitasnya memiliki dan atau berada di luar atau melampaui analisa metode ilmiah konvensional. Selama ini metode konvensional menggunakan prinsip kausalitas biasa yang bersifat mekanis sebagaimana ilmu alam memahami gejala alam (Muadz 2014: 53-54).

Pendekatan modern konvensional dalam analisa sistemnya meyakini bahwa setiap sistem yang kompleks, perilaku keseluruhan sistem dapat dimengerti sepenuhnya dengan mengamati sifat bagian-bagiannya. Proses ini dilakukan dengan memecah bagian-bagian dari sebuah sistem sosial ke unsur-unsur terkecilnya dan mengamati sifat, ciri dan perilaku dari bagian-bagian tersebut. Kemudian merekonstruksi sifat dan ciri-ciri dari bagianbagian tersebut berdasarkan hasil pengamatan (Muadz 2014: 54).

Pendekatan teori sistem menjelaskan gejala sistem sosial secara berbeda atau bertentangan dengan pendekatan modern konvensional. Teori sistem menjelaskan bahwa dalam ber- 
bagai level sistem, sistem mekanik hingga biologis ternyata memiliki ciri-ciri dan sifat dasar yang menyeluruh yang justru tidak ditemukan dalam bagian-bagiannya. Keseluruhan merupakan hasil dari interaksi bagianbagian yang memiliki sifat atau ciri-ciri yang lebih dari sekedar totalitas dari bagianbagiannya. Ada unsur lain yang muncul dalam interaksi, dan ketika dianalisa berdasarkan bagian-bagian sistem ada sifat-sifat sistem yang hilang atau rusak. Pendekatan sistem mengkritik pendekatan analitis modern konvensional bersifat reduksionis (Muadz 2014: 55).

Dalam pendekatan teori sistem, Parson menjelaskan bahwa organisasi manusia dibangun di atas relasi empat sistem yang berbeda-beda namun saling terkait dan membutuhkan. Sistem sosial terstruktur di dalamnya. Dinamikanya sangat ditentukan struktur yang membangun sistem tersebut. Elemenelemen struktural berkembang sesuai dengan tingkat keterkaitannya satu dengan yang lainnya. perubahan yang terjadi di luar sistem ikut serta mempengaruhi struktur sistem sosial tersebut berkembang. Keempat sistem tersebut meliputi: 1) Sistem budaya; yaitu sistem yang terkait dengan simbol-simbol budaya berupa ide, keyakinan, dogma, teknologi, bahasa, dan komponen-komponen simbolik lainnya. 2) Sistem sosial; yaitu sistem yang terkait dengan penginstitusian sosial, pembentukan hubungan sosial yang stabil dan pola interaksi sosial individu atau kelompok dalam masyarakat, merupakan fokus kajian sosiologis. 3) Sistem kepribadian; yaitu sistem yang terkait dengan komponen-komponen kepribadian diantaranya motif, kognisi, komit- men, dan keterampilan serta terkait dengan sistem pengambilan keputusan. 4) Sistem organismik; yaitu sistem yang terkait dengan aspek-aspek yang memberi energi bagi manusia. Perannya untuk membantu manusia beradaptasi terhadap perubahan di lingkungannya. (Turner dan Maryanski 2010: 127, 140)

Keempat sistem tersebut dalam kehidupan manusia saling berelasi satu dengan lainnya untuk mempertegas kontribusinya masingmasing dan terhadap satu dengan lainnya. Parson memberikan gambaran pola hubungan tersebut dengan "Hierarki Sibernetik Kendali" pada Gambar 1 (Turner dan Maryanski 2010: 142).

Merujuk pada kerangka pikir Parson tersebut maka bisa dipahami bahwa sistem dalam kehidupan manusia merupakan dinamika atau sirkulasi atas pergerakan informasi dan pemanfaatan energi. Informasi sebagai unsur yang dinamis berperan menghubungkan antar sistem, yang didukung oleh ketersediaan energi penggeraknya. Pembacaan pola hubungan sistem sosial dalam kerangka pemikiran parsonian tersebut, memberikan pemahaman bahwa sistem sosial memiliki gradasi tingkatan sesuai peran dan fungsinya. Sistem sosial memiliki beberapa tingkatan berdasarkan kebutuhannya dalam rangka untuk kelangsungan hidup dan saling ketergantungannya secara sistemik dalam jaringan kehidupan, yaitu (Turner dan Maryanski 2010: 100): 1) Tingkatan biologis. 2) Tingkatan psikologis. 3) Tingkatan sosial. 4) Tingkatan budaya (bersifat simbolik). 
Dimensi struktural dalam institusi dan sistem sosial menunjuk pada unsur-unsur permulaan suatu lembaga dan sistem sosial yang dianggap bebas dari skala rendah dan fluktuasi jangka pendek dalam hubungan sistem tersebut dengan situasi eksternalnya (Hamilton 1990: 186). Berdasarkan pada karakteristik tersebut maka dimensi struktural merupakan dimensi yang bersifat statis. Struktur dalam sistem-sistem sosial diperlakukan sebagai kerangka acuan tindakan yang terkandung dalam pola-pola budaya normatif terlembaga (Hamilton 1990: 187).

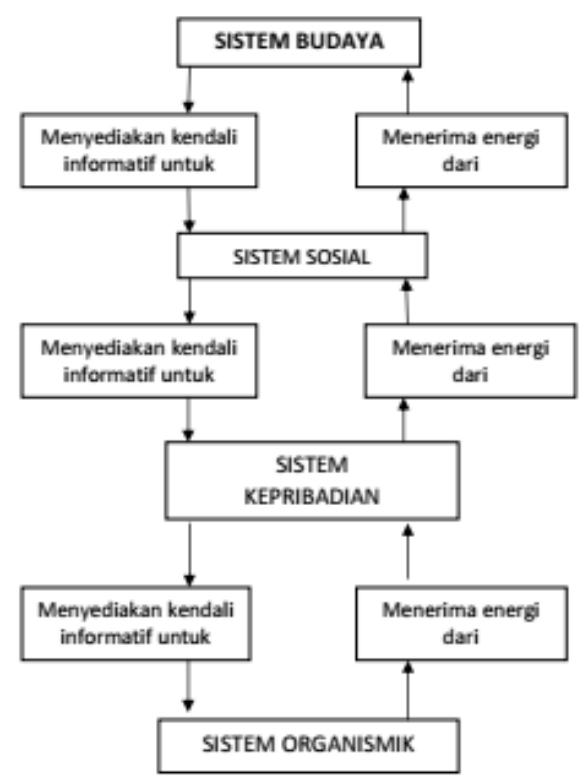

Gambar 1

"Hierarki Sibernetik Kendali

Dimensi fungsional menunjuk pada peran lembaga dan sistem sosial sebagai penengah atau mediasi atas kekonstanan relatif suatu struktur dari lembaga dan sistem sosial dengan relatifitas situasi atau kondisi lingkungan yang bersifat eksternal terhadap suatu lembaga dan sistem sosial (Hamilton 1990: 186187). Merujuk proposisi fungsional tersebut, maka suatu lembaga dan sistem sosial memiliki sifat dinamis. Dimensi fungsional dari lembaga dan sistem sosial merupakan aspek- aspek kerangka acuan yang mengandung caracara penyesuaian sistematis beroperasi dalam suatu hubungan yang berubah diantara seperangkat pola-pola struktur terlembaga tertentu dalam suatu sistem dengan seperangkat sistem-sistem lingkungan tertentu yang relevan (Hamilton 1990: 187).

\section{Perubahan Struktur dan Sistem Sosial}

Perubahan struktur sosial berlangsung pada aras kultur normatif (sistem nilai ter- 
penting) suatu sistem sosial tertinggi, yang diikuti oleh perubahan pada sub sistem yang ada dan dalam peranan sosial. Perubahan struktural sebagai fenomena perubahan fundamental dalam unit tertentu yang memungkinkan timbulnya perubahan pada unit yang lain, dan atau perubahan tingkat tertentu memungkinkan terjadinya perubahan pada tingkat yang lainnya (Leuer 1989: 113). Pada masyarakat yang belum maju kebudayaannya, perubahan struktural terjadi lebih banyak dipengaruhi oleh faktor-faktor eksternal atau di luar kebudayaan tersebut. Faktor eksternal mempengaruhi suatu struktur sosial sebagai konsekuensi dari pola relasi yang berlangsung diantara struktur sosial yang ada. Adanya beberapa aspek yang dominan dari suatu struktur sosial tertentu akan mempengaruhi elemen-elemen struktur sosial lainnya. pengaruh suatu struktur atas struktur sosial lainnya bisa bersifat lunak yang bersifat persuasif, dan atau bersifat menekan sehingga struktur sosial yang lain harus menerimanya.

Perubahan sistem sosial dalam pandangan Parson terkait dengan struktur sosialnya. Bentuk-bentuk perubahannya dikembangkan Parson berdasarkan ruang lingkup dan sifatsifatnya. Ada empat bentuk-bentuk perubahan sistem yang meliputi (Leuer 1989: 112-113): 1) Proses penyeimbangan sistem; berlangsung di dalam sistem itu sendiri. Proses ini dilakukan sebagai adaptasi di antara elemenelemen yang berubah. 2) Perubahan struktural dalam sistem sosial; bentuk-bentuk perubahan bersifat fundamental sehingga akan memberikan yang mendasar dan luas pengaruhnya pada sistem sosial. 3) Diferensiasi struktural; merupakan perubahan dalam sistem sosial yang berlangsung pada satu sub sistem atau lebih tetapi tidak menimbulkan perubahan secara keseluruhan. 4) Evolusi; merupakan perubahan dalam sistem sosial yang berlangsung sepanjang waktu, pelan-pelan dan melekat dalam dinamika sehari-hari. Perubahan jenis ini seringkali terjadi tidak terasakan oleh aktor-aktor dalam sistem.

Diferensiasi struktural merupakan proses perubahan pada subsistem tetapi tidak mengubah struktur sistem sosial secara keseluruhan. Dalam diferensiasi struktur nilai-nilai sudah mapan atau mendasar dan telah mengakar kuat dalam kehidupan suatu masyarakat dianggap tetap tidak berubah. Namun demikian bukan berarti tidak ada sama sekali perubahan pada nilai dasar budaya masyarakat. perubahan terjadi dalam nilai tetapi tidak pada pola budayanya (Leuer 1989: 113-114).

Perubahan yang bersifat umum dari struktur dan sistem sosial berupa diferensiasi. Perubahan ini merupakan bagian dari upaya adaptasi atas kondisi di dalam dan di luar struktur dan sistem sosial. faktor yang mempengaruhinya ada dua; kesadaran sendiri karena melihat potensi internal dan eksternal memerlukan perubahan, agar eksistensinya masih bisa bertahan. Tekanan dari luar yang memposisikan suatu struktur dan sistem sosial tidak berdaya, sehingga perubahan dilakukan untuk memperkuat daya tahan dalam rangka mempertahan posisi peran dan fungsi struktur dan sistem sosial di masyarakat. Dalam perspektif Parsonian ada beberapa aspek yang 
bisa digunakan untuk menjelaskan terjadinya diferensiasi struktural pada suatu masyarakat (institusi sosial) yang meliputi (Leuer 1989: 114-115): 1) Kegagalan dalam pencapaian tujuan. 2) Terjadinya masalah hubungan pada batas pencapaian tujuan dengan subsistem lainnya. 3) Adanya upaya penyeimbangan atas kegagalan pencapaian tujuan dalam hubungannya dengan subsistem lainnya, artinya antara unsur-unsur fasilitas dan ganjaran dengan unsur-unsur normatif sistem yang diharapkan.

Perubahan struktur sosial dipengaruhi faktor internal (endogen) dan faktor eksternal (eksogen) dari suatu sistem sosial. Faktor internal terjadi akibat adanya keteganganketegangan internal dalam menyeimbangkan in put dan out put di antara sub sistem sosial yang membangun suatu struktur sosial. Ketegangan internal merupakan suatu kondisi dalam hubungan antar sub sistem mengalami tekanan untuk berubah dan cara berubahnya menyebabkan ketidakseimbangan sistem. Faktor eksternal terjadi akibat dari relasi yang tidak bisa dielakkan dengan sistem sosial lainnya. Beberapa aspek eksternal meliputi; organisme, kepribadian dan kultur (Leuer 1989: 140).

\section{Kesimpulan}

Penggunaan analisis struktur dan sistem sosial dalam memahami dinamika masyarakat secara sosiologis akan selalu relevan. Keduanya merupakan aspek mendasar dari dinamika sosial masyarakat dalam konteks kapan pun dan dimana pun. Pemahaman atas konsep, proses pembentukan, sifat, fungsi dan perubahannya dalam masyarakat merupakan aspek mendasar untuk mampu menjelaskan beragam fenomena sosiologis. Perkembangan keduanya pada beberapa aspek mengalami elaborasi seiring dengan perkembangan masyarakat dan upaya-upaya akademik sosiolog memahami kompleksitas masyarakat. Banyak sosiolog mengembangkan keduanya pada aras wacana dan praksis dalam beragam aktivitas akademik; penelitian, diseminasi melalui diskusi atau seminar dan penulisan karya ilmiah dalam berbagai jurnal sosiologi. Pengembangan wacana dan praksis tentang struktur dan sistem sosial merupakan kerja akademik yang lama dan membutuhkan energi pemikiran.

Berdasarkan kajian di atas dapat disimpulkan bahwa pembentukan struktur sosial tidak berlangsung secara instan dalam suatu masyarakat. proses evolutif merupakan pembentukan struktur sosial yang bertahap. Struktur sosial memiliki hubungan timbal balik dengan individu sehingga perubahan struktur sosial dapat disebabkan oleh perubahan individual dalam masyarakat, dan perubahan individu dapat diakibatkan oleh perubahan struktur sosial.

Keberadaan struktur dan sistem sosial pada aras praksis dipengaruhi oleh faktor internal dan eksternal suatu masyarakat. Komitmen internal masyarakat dalam mempertahan dan atau merubah keduanya sangat menentukan. Perubahan sosial dari masyarakat luar telah menekan struktur dan sistem sosial untuk berubah secara evolutif dan atau revolutif. 
Struktur sosial memiliki kaitan erat dengan sistem sosial. Dilihat dari perspektif sosiologis sistem sosial memiliki prinsip otonomi. Sistem sosial dalam idealitasnya memiliki mekanisme organisasi tertentu, yang memungkinkannya mampu membangun dan mengkonservasi secara terus menerus ciri keutuhan dirinya sebagai identitas eksistensialnya. Setiap tekanan baik yang bersifat internal maupun eksternal akan dapat dikelola secara sistemik dan otonom untuk mendukung perbaikan dan penguatan sistem sehingga tidak mengganggu dan atau merusak elemen-elemen sistem sosial itu sebagai satu kesatuan dalam struktur sosial yang ada.

Perubahan struktur sosial berlangsung pada aras kultur normatif (sistem nilai terpenting) suatu sistem sosial tertinggi, yang diikuti oleh perubahan pada sub sistem yang ada dan dalam peranan sosial. Perubahan struktural sebagai fenomena perubahan fundamental dalam unit tertentu yang memungkinkan timbulnya perubahan pada unit yang lain, dan atau perubahan tingkat tertentu memungkinkan terjadinya perubahan pada tingkat yang lainnya.[]

\section{Daftar Pustaka}

Abercrombie, Nicholas, Stephen Hill, dan Bryan S. Turner. 2010. Kamus Sosiologi. terj. Desi Noviyani. Yogyakarta: Pustaka Pelajar.

Giddens, Anthony. 2009. Problematika Utama dalam Teori Sosial. terj. Daryatna. Yogyakarta: Pustaka Pelajar.
Hamilton, Peter, ed. 1990. Talcot Parsons dan Pemikirannya Sebuah Pengantar. Yogyakarta: Tiara Wacana.

Kroeber, A. L. dan Talcott Parsons. 1958. "The Concept of Culture and of Social System." The American Sociological Review 23: 582-3.

Kuper, Adam dan Jesica Kuper. 2000. Ensiklopedi Ilmu-ilmu Sosial. terj. M. Haris. Jakarta: RajaGrafindo Persada.

Leuer, Robert H. 1989. Perspektif tentang Perubahan Sosial. terj. Alimandan. Jakarta: Bina Aksara.

Muadz, M. Husn. 2014. Anatomi Sistem Sosial. Mataram: Institut Pembelajaran Gelar Hidup.

Rudjansyah, Tony. 1997. "Kaomu, Papara dan Walaka: Satu Kajian Mengenai Struktur Sosial dan Ideologi Kekuasaan di Kesultanan Wolio." Jurnal Antropologi Indonesia 51.

Smelser, Neil J. 1998. "Social Structure." dalam Handbook of Sociology, ed. S. J. Smelser. Beverly Hills, CA: Sage.

Soekanto, Soerjono. 1993. Beberapa Teori Sosiologi tentang Struktur Masyarakat. Jakarta: Raja Grafindo Persada.

Susilo, Edy. 2010. Dinamika Struktur Sosial dalam Ekosistem Pesisir. Malang: UB Press.

Turner, Jonathan H. dan Alexandra Maryanski. 2010. Fungsionalisme. ed. Anwar Effendi. Yogyakarta: Pustaka Pelajar.

Wenger, Etienne. 2008. "Learning Social System." in V9N5 Cover 4, Sept 2008. 